\section{Pick of the paperbacks}

- Chemical Evolution: Origins of the Elements, Molecules and Living Systems by Stephen F. Mason, Oxford University Press, $£ 8.95$. For a review see Nature 351, 199 (1991).

- Symbiosis in Cell Evolution: Microbial Communities in the Archean and Proterozoic Eons, second edition, by Lynn Margulis. W. H. Freeman, £27.95.

- Fractals, Chaos, Power Laws by Manfred Schroeder, W. H. Freeman, $\$ 19.95, £ 15.95$. For a review see Nature 350, 524 (1991).

- The Great Mambo Chicken and the Transhuman Condition: Science Slightly Over the Edge by Ed Regis. Penguin, £6.99. "Virtuoso science writing of rare vigour and mastery", wrote Walter Gratzer in a review in Nature 354, 338 (1991).
The Character of Physical Law by Richard Feynman, a series of lectures given at Cornell University in the mid1960s. Penguin, $£ 5.99$ (with an introduction by Paul Davies); MIT Press, $£ 5.95, \$ 8.95$.

- Another Fine Math You've Got Me Into by lan Stewart, a collection of mathematical puzzles. W. H. Freeman, $\$ 13.95, £ 10.95$.

- The Changing Atmosphere: A Global Challenge by John Firor. Yale University Press, $\$ 9, £ 5$. For a review see Nature 349, 472 (1991).

Discovering Egyptian Hieroglyphs: A Practical Guide by Karl-Theodor Zauzich. Thames and Hudson, $£ 7.95$. - Sell Yourself To Science: The Complete Guide to Selling Your Organs, Body Fluids, Bodily Functions and Being a Human Guinea Pig by Jim Hogshire. Loompanics, Washington, $\$ 16.95$.

\section{A book for burning}

\section{Martin Gardner}

Spontaneous Human Combustion. By Jenny Randles and Peter Hough. Robert Hale: 1992. Pp. 224. £14.95.

HERE we go again - another worthless book pandering to public obsession with the paranormal. The authors, Jenny Randles and Peter Hough, have separately and in tandem perpetrated previous books about UFOs, crop circles, witchcraft and similar wonders. In this book they do their best to persuade readers that there have been hundreds, perhaps thousands, of cases of people bursting into flames from causes science cannot fathom.

The simplest explanation of most such burnings is that victims fall asleep, often intoxicated, and set fire to their clothes with a cigarette, cigar or pipe. If elderly, fat and dehydrated, and given sufficient time, almost all of the body can be reduced to ashes. Because the media love to sensationalize, sometimes to lie, the myth of spontaneous human combustion continues to thrive.

Not a single chemist or physicist of repute is cited in this shameful book, and for an obvious reason. None believes that a human body can spontaneously catch fire. And virtually all the periodicals cited in the book are not scientific journals but obscure fringe magazines devoted to the paranormal.

The authors discuss a variety of ways in which a body might ignite apart from contact with such things as burning cigarettes and fireplaces. Perhaps ball lightning enters a room to smite the victim. Static electricity? (The authors call this a "shocking suggestion".) Forcefields from high tension wires? Psychic curses from enemies? Poltergeists? "Kundalini fire", an energy that Yogis claim pervades a person's astral body? One "researcher" thinks the body may contain a subatomic particle - he calls it a "pyrotron" - that undergoes a chain reaction unknown to physicists.

The authors take seriously what they call a "phosphinic fart". That expelled gas is highly inflammable is easily demonstrated. Could it be, the authors wonder, that such gas might float up through clothing to be fired by a cigarette?

The sole merits of this preposterous book are that it catalogues more than a hundred alleged cases of spontaneous human combustion, cites earlier books even worse than this one, and briefly considers cases of the phenomenon in fiction. The earliest example is in Charles Brockton Brown's novel Wieland. Others include Nicolai Gogol's Dead Souls, Captain Marryat's Jacob Faithful, Herman Melville's Redburn and Emile Zola's Le Docteur Pascal. The most famous instance is the spontaneous human combustion of a drunken $\mathrm{Mr}$ Krook in Charles Dickens's Bleak House. Dickens was soundly trounced by George Henry Lewes, George Eliot's live-in lover, for treating spontaneous human combustion as a fact. (See Blackwood's Edinburgh Magazine, volume 89, April 1861.) Their debate was notable among the many controversies about the subject that raged in nineteenth-century England.

The jacket of Spontaneous Human Combustion shows a grizzly photograph of the remains of Mary Reeser, a plump 67-year-old resident of St Petersburg, Florida, who burned to death in 1951 .
The authors devote a chapter to this most famous of all modern cases. When Mrs Reeser caught fire, she had not eaten dinner, was wearing a flammable nightgown, had taken two Seconal tablets and was smoking a cigarette. When her son kissed her goodnight before leaving, she said she intended to take two more sleeping pills. Not until the following morning were her ashes found. The well-stuffed chair in which she sat was also consumed. The authors cannot imagine why the house did not burn down, ignoring the fact that the floor was concrete and a ceiling beam was burning when firemen arrived.

The Federal Bureau of Investigation's laboratory report on the case, based on many similar investigations, stated: "Once the body starts to burn there is enough fat and other inflammable substances to permit varying amounts of destruction to take place. Sometimes this destruction by burning will proceed to a degree which results in almost complete combustion of the body." Yet the authors strive valiantly to avoid the obvious and to convince readers that something strange and inexplicable had felled Mrs Reeser.

Why are cases of alleged spontaneous human combustion so much rarer today than in past centuries? Because reporting is more accurate and forensic methods have improved. In 1982 the US press had a field day when a Chicago woman was said to have burst into flames while walking along a street. When a medical examiner investigated, he found that the woman had been dead for 12 hours, and her clothes doused with gasoline.

On their last page the authors conclude that spontaneous human combustion is "triggered by forces that are just as puzzling to us as electricity was to Leonardo da Vinci. Yet, like electricity, it is probably a natural - not supernatural - energy dormant in our midst. If we can learn to tap into it, to harness its raw power and perhaps control its anger, then who knows what advantages it might bring to our children?"

Elsewhere, indulging in another pun, the authors call the "mystery' a "burning question" for modern science. It is not a burning question. It is not even a question. Not a single textbook on forensic medicine written this century considers the phenomenon a possible cause of death. The only burning question is how today's cynical publishers can maintain a clear conscience when they flood the market with absurd potboilers solely for the purpose of extracting money from an ill-informed, gullible public.

Martin Gardner is at 110 Glenbrook Drive, Hendersonville, North Carolina 28739, USA. 